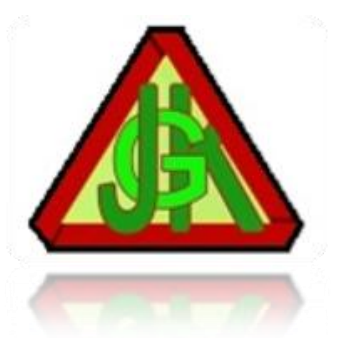

\title{
PENGARUH SELF-COMPASSION THERAPY TERHADAP TINGKAT DEPRESI PASIEN DIABETES MELITUS
}

\author{
I Gusti Ayu Harini ${ }^{1}$, I Putu Yoan Sugiantara ${ }^{2}$, I Wayan Candra ${ }^{3}$ \\ 1,2,3 Politeknik Kesehatan Kemenkes Denpasar, \\ Denpasar, Indonesia \\ e-mail: iga.harini@gmail.com ${ }^{1}$, yoansugiantara123@gmail.com ${ }^{2}$, \\ suryabhrihaspathi@gmail.com ${ }^{3}$
}

\begin{abstract}
Abstrak
Penderita Diabetes Mellitus (DM) memiliki risiko terkena depresi lebih tinggi. Untuk mengatasi depresi pada pasien dengan DM, perlu terapi nonfarmakologi seperti self-compassion therapy. Tujuan penelitian ini mengetahui pengaruh selfcompassion therapy terhadap tingkat depresi pasien diabetes melitus di Wilayah Kerja Puskesmas I Denpasar Barat tahun 2021. Penelitian ini menggunakan metode pre experimental berjenis one-group pre-post test design. Pengambilan sampel dengan non-probability sampling berjenis purposive sampling. Responden 17 orang. Instrumen penelitian Beck Depression Inventory-II (BDI-II). Uji normalitas dengan uji Shapiro-Wilk. Uji hipotesis dengan Wilcoxon Signed Ranks Test. Hasilnya menunjukan sebagian besar responden masuk kategori depresi ringan 10 orang $(58,8 \%)$, sisanya depresi sedang 7 orang $(41,2 \%)$ sebelum diberikan self-compassion therapy. Setelah perlakuan, tingkat depresi mengalami penurunan, depresi sedang 3 orang $(17,6 \%)$, depresi ringan 9 orang $(52,9 \%)$, dan tidak depresi 5 orang $(29,4 \%)$. Setelah dianalisis $p$-value pada Sig.(2-tailed $)=$ $0,000<$ alpha $(0,05)$. Kesimpulannya bahwa ada pengaruh self-compassion therapy terhadap tingkat depresi pasien diabetes melitus di Wilayah Kerja Puskesmas I Denpasar Barat tahun 2021, artinya menurunkan tingkat depresi. Oleh karena itu, diharapkan self-compassion therapy dapat diterapkan pada pasien dengan DM yang mengalami depresi.
\end{abstract}

\section{Kata kunci : Self-compassion, Depresi, Diabetes melitus}

\begin{abstract}
People with Diabetes Mellitus (DM) have a higher risk of developing depression. To treat depression in patients with DM, non-pharmacological therapies such as self-compassion therapy are needed. The aims of research to determine effect selfcompassion therapy to depression levels diabetes mellitus patients in Work Area of Puskesmas I Denpasar Barat on 2021. This research used the method preexperimental with one-group pre-post test design. Sampling with non-probability sampling with purposive sampling. Respondents were 17 people. The research instrument used Beck Depression Inventory-II. The normality test uses ShapiroWilk test. Hypothesis testing using Wilcoxon Signed Ranks Test. The results showed that most respondents were in mild depression category 10 people
\end{abstract}


I Gusti Ayu Harini, I Putu Yoan Sugiantara, I Wayan Candra. Desember 2021. 14 (2): 185-199

(58.8\%), the rest were moderate depression (41.2\%) before being given selfcompassion therapy. After treatment level of depression decreased, 3 people had moderate depression (17.6\%), 9 people had mild depression (52.9\%), and least 5 people not depression (29.4\%). After analysis, p-value was obtained at Sig. (2tailed $)=0.000$ <alpha (0.05). The conclusion was that there is an effect of selfcompassion therapy to depression levels on diabetes mellitus patients in Work Area Puskesmas I Denpasar Barat on 2021, meaning reduce depression levels Therefore, it is hoped that self-compassion therapy can be applied to patients with DM who experience depression.

Key words: Self-compassion, Depression, Diabetes mellitus

\section{PENDAHULUAN}

Diabetes Melitus merupakan penyakit kronis yang terjadi ketika pankreas tak mampu memproduksi insulin yang cukup, atau ketika tubuh tidak efektif menggunakan produksi insulinya ${ }^{(1)}$. Menurut Misnadiarly (2006), DM adalah penyakit kronis yang ditandai dengan kadar gula darah lebih dari semestinya yakni gula darah sewaktu sama atau lebih dari $200 \mathrm{mg} / \mathrm{dl}$, dan juga gula darah puasa sama atau diatas $126 \mathrm{mg} / \mathrm{dl}^{(2)}$. Kerusakan insulin ini akan membuat leven glukosa darah yang tinggi, dan hal tersebut adalah tanda umum dari $\mathrm{DM}^{(3)}$. Diabetes dalam jangka panjang dapat memicu timbulnya komplikasi pada tubuh manusia. Diabetes masuk dalam jajaran empat penyakit tidak menular yang menjadi masalah kesehatan di dunia ${ }^{(1)}$.

Diperkirakan 422 juta orang dewasa terkena DM di tahun 2014. Prevalensi DM dunia pengalami peningkatan dua kali lipat di tahun 1980, dari 4,7\% menjadi $8,5 \%^{(1)}$. International Diabetes Federation (2013) mengatakan untuk angka kejadian DM di dunia adalah 382 juta jiwa, dimana proporsi DM tipe 2 adalah 95\% dari populasi di dunia ${ }^{(2)}$. Prevalensi diabetes melitus di Indonesia tahun 2013 yakni sebesar (2,1\%). Sebanyak 31 provinsi $(93,9 \%)$ menunjukkan angka kenaikan prevalensi penderita DM yang cukup berarti ${ }^{(2)}$. Tahun 2018 prevalensi diabetes melitus di Indonesia usia $\geq 15$ tahun sebesar $(8,9 \%)$, terdiri atas $(1,2 \%)$ laki-laki dan (1,8\%) perempuan. Riskesdas (2018) menyebutkan kalau penderita DM tertinggi ada di rentang usia 55-64 tahun dengan persentase (6,3\%). Di wilayah perkotaan, persentase diabetes tercatat lebih tinggi yakni $(1,9 \%)$ 
I Gusti Ayu Harini, I Putu Yoan Sugiantara, I Wayan Candra. Desember 2021. 14 (2): 185-199

dibandingkan di desa dengan presentase (1,0\%). Menurut Dinas Kesehatan Provinsi Bali (2017) sekiranya terdapat 16.254 penduduk yang berusia $>40$ tahun menderita diabetes ${ }^{(3)}$. Berdasarkan hasil wawancara dan juga studi pendahuluan yang dilakukan, di wilayah kerja Puskesmas I Denpasar Barat pada tahun 2019 terdapat 1.999 orang yang tercatat menderita DM yang terdiri dari laki-laki sebanyak 1.134 orang (57\%) dan perempuan sebanyak 865 orang (43\%). Akan tetapi angka tersebut menurun (3\%) karna pada tahun 2020 total penderita DM di wilayah kerja Puskesmas I Denpasar Barat adalah sebanyak 1.942 orang yang terdiri dari laki-laki-laki sebanyak 1.334 orang (69\%) dan perempuan 608 orang $(31 \%)$.

Depresi merupakan gangguan pada perasaan yang ditandai dengan afek disforik atau kehilangan kegembiraan dan gairah disertai dengan gejala seperti sulit tidur serta menurunnya selera makan. Pasien DM ini memiliki risiko dua kali lipat depresi dibandingkan orang biasa. Hasil penelitian Mustika, Candra dan Yunianti (2017) yang terkait dengan tingkat depresi untuk pasien DM menemukan bahwa sebanyak $(73,2 \%)$ mengalami depresi. Penelitian lain oleh Eashwar, Gopalakrishnan dan Umadevi (2017) menyatakan dari 300 pasien, terdapat 119 pasien $(39,7 \%)$ yang mengalami depresi, $(17,3 \%)$ depresi ringan, (13\%) depresi sedang, $(6,7 \%)$ depresi sedang hingga berat, dan $(2,7 \%)$ depresi berat ${ }^{(4)}$. Depresi pada pasien Diabetes Melitus dapat memicu berbagai masalah. Hal ini membuat semakin buruknya perawatan diri, motivasi berobat secara intensif,menurunnya kualitas hidup dan kontrol glikemik karena kurangnya pemantauan di aspek psikologi khsusnya skrining depresi ${ }^{(5)}$.

Skrining depresi pada pasien DM dapat menggunakan instrument Beck Depression Inventory-II (BDI-II) yang terdiri dari 21 item untuk menaksir tingkatan depresi seseorang(6). Pemberian intervensi keperawatan jiwa non farmaklologi untuk mengurangi depresi pasien DM perlu dilakukan untuk mengurangi dampak yang diakibatkan oleh depresi ini. Terapi efektif yang dapat di berikan adalah Self-Compassion Therapy. Menurut Neff (2003) SelfCompassion Therapy merupakan bentuk terapi perasaan terbuka pada kesulitan yang dialami, memahami kegagalan yang dialami, dan sadar bahwa pengalaman 
I Gusti Ayu Harini, I Putu Yoan Sugiantara, I Wayan Candra. Desember 2021. 14 (2): 185-199

diri adalah bagian dari pengalaman umum $^{(7)}$. Individu dengan self-compassion digambarkan sebagai orang yang tidak mudah menyalahkan diri, memperbaiki kesalahan, mengubah perilaku buruk dan menghadapi tantangan baru ${ }^{(8)}$. Selfcompassion berasal dari kata compassion yang artinya rasa belas kasih yang dikemukakan oleh Echols \& Shadily (2000) dalam ${ }^{(9)}$. Pada penelitian sebelumnya, self-compassion banyak dipakai memprediksi kesehatan mental. Leary dkk. (2007) menambahkan self-compassion dapat meredam reaksi terhadap peristiwa tidak menyenangkan ${ }^{(7)}$.

Tujuan penelitian ini adalah untuk membuktikan pengaruh Self-Compassion Therapy terhadap tingkat depresi pasien diabetes melitus di wilayah kerja Puskesmas I Denpasar Barat tahun 2021.

\section{METODE}

Penelitian ini menggunakan desain penelitian pre-experimental dengan penelitian yang digunakan yaitu One Group pre-post test design. Jadi pada penelitian ini akan dilakukan pengukuran sebanyak dua kali yaitu sebelum diberikan terapi dan setelah diberikan terapi. Populasi penelitian ini adalah seluruh pasien diabetes melitus di Wilayah Kerja Puskesmas I Denpasar Barat yang berjumlah 1.942 orang dengan jumlah sampel 17 pasien DM yang memenuhi kriteria inklusi. Data primer dikumpulkan meliputi usia, jenis kelamin, dan data hasil pemeriksaan pengukuran tingkat depresi dengan instrumen Beck Depression Inventory-II yang dilakukan sebelum dan sesudah perlakuan. Perlakuan yang diberikan adalah terapi Self-Compassion Tehrapy. Teknik analisa data menggunakan analisis univariat dan bivariat. Analisa univariat digunakan untuk mendapatkan nilai dan persentase karakteristik sampel meliputi usia dan jenis kelamin. Analisa bivariat digunakan untuk menganalisis hubungan karakteristik dengan tingkat depresi sebelum diberikan self-compassion therapy menggunakan uji Chi-Square, dan pengaruh Self-Compassion Therapy terhadap tingkat depresi pasien DM dengan uji Wilcoxon Signed Rank Test. 
I Gusti Ayu Harini, I Putu Yoan Sugiantara, I Wayan Candra. Desember 2021.

14 (2): 185-199

\section{HASIL DAN PEMBAHASAN}

Karakteristik responden berdasarkan usia dan jenis kelamin disajikan dalam tabel 1 dan 2. sedangkan tingkat depresi sebelum, sesudah diberikan SelfCompassion Therapy, uji normalitas data depresi, uji hipotesis pengaruh, tingkat depresi berdasarkan karakteristik usia dan, jenis kelamin disajikan pada tabel 3 sampai dengan 8 .

Tabel 1. Distribusi Frekuensi Responden Berdasarkan Usia

\begin{tabular}{ccc}
\hline Usia (Tahun) & $\mathbf{n}$ & $\mathbf{\%}$ \\
\hline $20-30$ & 0 & 0 \\
$31-59$ & 14 & 82,4 \\
$\geq 60$ & 3 & 17,6 \\
\hline Total & 17 & 100 \\
\hline
\end{tabular}

Tabel 1 menunjukan bahwa usia subyek penelitian yang paling banyak ada pada rentang usia 31-59 tahun yaitu sebanyak 14 orang $(82,4 \%)$.

Tabel 2. Distribusi Frekuensi Responden Berdasarkan Jenis Kelamin

\begin{tabular}{ccc}
\hline Jenis Kelamin & $\mathbf{n}$ & $\%$ \\
\hline Laki Laki & 7 & 41,2 \\
Perempuan & 10 & 58,8 \\
\hline Total & 17 & 100 \\
\hline
\end{tabular}

Tabel 2 menunjukan jenis kelamin subyek penelitian terpaling banyak yaitu perempuan sebanyak 10 orang $(58,8 \%)$.

Tabel 3. Distribusi Frekuensi Tingkat Depresi Sebelum perlakuan SelfCompassion Therapy

\begin{tabular}{ccc}
\hline Depresi & N & \% \\
\hline Tidak Depresi & 0 & 0 \\
Depresi Ringan & 10 & 58,8 \\
Depresi Sedang & 7 & 41,2 \\
Depresi Berat & 0 & 0 \\
\hline Total & 17 & 100 \\
\hline
\end{tabular}

Tabel 3 menunjukan skor depresi sebelum diberikan perlakuan selfcompassion therapy sebagian besar ada pada kategori depresi ringan yaitu sebanyak 10 orang $(58,8 \%)$. 
I Gusti Ayu Harini, I Putu Yoan Sugiantara, I Wayan Candra. Desember 2021.

14 (2): 185-199

Tabel 4. Distribusi Frekuensi Tingkat Depresi Sesudah perlakuan SelfCompassion Therapy

\begin{tabular}{ccc}
\hline Depresi & N & \% \\
\hline Tidak Depresi & 5 & 29,4 \\
Depresi Ringan & 9 & 52,9 \\
Depresi Sedang & 3 & 17,6 \\
Depresi Berat & 0 & 0 \\
\hline Total & 17 & 100 \\
\hline
\end{tabular}

Tabel 4 menunjukan skor depresi subyek penelitian sesudah diberikan perlakuan self-compassion therapy sebagian besar ada pada kategori depresi ringan yaitu sebanyak 9 orang $(52,9 \%)$.

Uji normalitas data perlu dilakukan sebelum melakukan pengujian hipotesis untuk mengetahui teknik uji hipotesis yang akan digunakan. Uji normalitas yang dilakukan bertujuan untuk mengetahui sebaran data pada variabel yang berdistribusi normal atau tidak. Uji normalitas data ini dilakukan menggunakan uji Shapiro-Wilk karena jumlah subyek penelitian kurang dari 50 orang

Tabel 5. Hasil Uji Normalitas Data Depresi

\begin{tabular}{ccc}
\hline \multirow{2}{*}{ Variabel } & \multicolumn{2}{c}{ Uji Shapiro-Wilk } \\
\cline { 2 - 3 } & $\mathbf{N}$ & $\boldsymbol{p}$ \\
\hline Pre Test Depresi & 17 & 0,048 \\
\hline Post Test Depresi & 17 & 0,014 \\
\hline
\end{tabular}

Tabel 5 menunjukan hasil uji normalitas sebaran pada variabel depresi sebelum diberikan perlakuan self-compassion therapy didapatkan nilai $p=0,048$ yang artinya hasil tersebut lebih kecil dari $p=0,05$ dan sehingga data tidak berdistribusi normal. Hasil uji normalitas pada variabel depresi sesudah diberikan perlakuan self-compassion therapy didapatkan nilai $p=0,014$ yang berarti hasil tersebut juga lebih kecil dari $p=0,05$ sehingga data tidak berdistribusi normal.

Uji hipotesis yang digunakan yaitu uji non parametrik test yakni uji Wilcoxon Signed Ranks Test karena data tidak berdistribusi normal. 
I Gusti Ayu Harini, I Putu Yoan Sugiantara, I Wayan Candra. Desember 2021. 14 (2): 185-199

Tabel 6. Hasil Uji Hipotesis Pengaruh Self-Compassion Therapy Terhadap Depresi

Hasil Uji Wilcoxon Sign Rank Test

Asymp. Sig. (2-tailed) 0,000
Tabel 6 menunjukan perolehan hasil uji statistik Wilcoxon yaitu hasil $p$ -
value pada kolom $=0,000<$ alpha $(0,05)$ yang menunjukan bahwa terdapat atau
ada pengaruh dalam pemberian perlakuan Self-Compassion Therapy terhadap
depresi pada subyek penelitian di Wilayah Kerja Puskesmas I Denpasar Barat
tahun 2021, bahwa Self-Compassion Therapy dapat menurunkan tingkat depresi
pada pasien diabetes melitus.

\section{Tingkat Depresi Sebelum Diberikan Self-Compassion Therapy}

Hasil penelitian ini menunjukan sebagian besar subyek mengalami depresi ringan yaitu sebanyak 10 orang $(58,8 \%)$ sebelum diberikan perlakuan selfcompassion therapy. Penelitian yang dilakukan oleh Supriati $(2016)^{(10)}$ dengan judul Hubungan Dukungan Keluarga dengan Kejadian Depresi pada Pasien Diabetes Mellitus di Rumah Sakit Muhammadiyah Gresik dengan jumlah subyek penelitian sebanyak 34 orang, menunjukan hasil yakni sebagian besar subyek penelitian yaitu sebanyak 22 orang (62\%) yang mengalami masalah yakni depresi.

Hasil penelitian lainnya yang dilakukan oleh Umamah \& Hidayah $(2017)^{(11)}$ dengan judul The Laughter Therapy on the Depression Level Experienced by the Elderly in UPTD Panti Griya Wreda Surabaya dengan jumlah subyek penelitian sebanyak 28 orang. Penelitian ini menunjukan hasil sebagian besar subyek penelitian yaitu sebanyak 24 orang $(85,7 \%)$ mengalami depresi ringan, depresi sedang, dan juga depresi berat.

Subyek penelitian yang terdiagnosis kronis terkena penyakit seperti diabetes melitus akan merasa terkejut dan kemudian akan mengalami cemas berlebihan, kehilangan rasa percaya diri dan juga penghargaan diri atau self-esteem sehingga dapat mengakibatkan timbulnya depresi. Hal ini akan membuat buruknya kontrol glikemik, manajemen diet yang buruk, perawatan diri yang kurang baik, hingga komplikasi akibat penyakit diabetes melitusnya ${ }^{(12)}$. 
I Gusti Ayu Harini, I Putu Yoan Sugiantara, I Wayan Candra. Desember 2021. 14 (2): 185-199

Pendapat dari peneliti adalah bahwa sebagian besar subyek penelitian yang dalam hal ini pasien diabetes melitus di Wilayah Kerja Puskesmas I Denpasar Barat tahun 2021 ini mengalami depresi, hal tersebut disebabkan karena beberapa subyek penelitian telah memiliki riwayat komplikasi terdahulu dari penyakit diabetes melitusnya seperti diabetic foot dan juga retinopati sehingga mempengaruhi fisik maupun psikologis para subyek penelitian. Selain itu sebagian kecil dari para subyek penelitian juga sudah mengetahui bahwa posisi mereka adalah sebagai komorbid yang rentan atau berisiko mengalami masalah yang lebih serius lagi apabila terinfeksi Covid-19. Penanganan seperti pemberian obat untuk mengontrol glukosa darah belum sepenuhnya mampu mengatasi masalah untuk gangguan psikologis ini, jadi perlunya intervensi khusus untuk penanganan gangguan psikologis sangat perlu dilakukan agar tidak mengalami masalah seperti depresi sehingga perawatan diri menjadi lebih buruk ${ }^{(13)}$.

\section{Tingkat Depresi Sesudah Diberikan Self-Compassion Therapy}

Hasil penelitian menunjukan sebagian besar subyek penelitian mengalami depresi ringan yaitu 9 orang (52,9\%). 7 orang (41,2\%) dari 17 subyek penelitian yang sebelumnya masuk kategori depresi sedang, sesudah diberikan perlakuan berkurang menjadi 3 orang $(17,6 \%)$ dengan skor yang menurun. 10 orang $(58,8 \%)$ dari 17 subyek penelitian yang sebelumnya masuk kategori depresi ringan, sesudah diberikan perlakuan self-compassion therapy, 5 orang $(50,0 \%)$ dari 10 orang tadi) skor depresinya menurun dan dikategorikan tidak depresi dan sisanya atau 5 orang lagi (50,0\% dari 10 orang) tetap dikategorikan depresi ringan namun dengan skor yang menurun.

Penelitian lain yang dilakukan oleh Tsani, Hartanti dan Elishabeth (2020) ${ }^{(14)}$ dengan judul Self-Compassion Intervention Untuk Menurunkan Depresi Remaja Penyintas Sex Abuse menunjukan bahwa pemberian intervensi self-compassion berpengaruh pada depresi remaja penyintas sex abuse. Secara deskriptif terlihat skor BDI-II responden 1 yang mulanya memiliki rata-rata 28 (kategori sedang) turun menjadi 22 (kategori sedang), sedangkan pada responden 2 mulanya memiliki rata-rata 19 (kategori ringan) turun menjadi 14 (kategori ringan). 
I Gusti Ayu Harini, I Putu Yoan Sugiantara, I Wayan Candra. Desember 2021. 14 (2): 185-199

Penelitian lain yang dilakukan oleh Chairunnisa dan Fourianalistyawati (2019) ${ }^{(7)}$ berjudul Peran Self-Compassion dan Spiritualitas Terhadap Depresi Pada Ibu Hamil dengan responden sebanyak 125 orang menunjukan bahwa setelah pemberian self-compassion therapy tingkat depresi responden menurun, sehingga self-compassion therapy berpengaruh terhadap depresi ibu hamil dengan hasil analisis data $p$-value $0,019<(0,05)$.

Menurut American Diabetes Association $(2017)^{(15)}$ pengkajian terhadap kesehatan mental dan juga psikologis sangat penting direkomendasikan dan diberikan kepada subyek penelitian pasien diabetes melitus agar mepermudah dalam pemberian psikoterapi dan intervensi lain sehingga kesehatan mental dapat meningkat. Banyak jenis medikasi atau pengobatan yang efektif untuk mengobati depresi ini, akan tetapi kombinasi farmakologi dan juga psikoterapi akan lebih efektif dalam memberikan dampak baik bagi masalah depresi subyek penelitian yaitu pasien diabetes melitus.

Menurut pendapat dari peneliti bahwa untuk memberikan asuhan kepada subyek penelitian pasien diabetes melitus yang memiliki masalah kesehatan seperti depresi tidak hanya dengan psikoterapi saja. Perlunya kolaborasi dengan obat atau medikasi farmakologi akan membantu subyek penelitian untuk dapat mengontol penyakit atau masalah diabetes yang dimilikinya. Sehingga emosi dan juga kontrol penyakit dapat membaik secara beriringan ${ }^{(13)}$.

\section{Pengaruh Pemberian Self-Compassion Therapy Terhadap Tingkat Depresi Subyek Penelitian}

Hasil penelitian ini menunjukan pada pengolahan data uji statistik Wilcoxon mendapatkan hasil $p$-value pada kolom $=0,000$ yang dalam hal ini menunjukan bahwa ada pengaruh pemberian perlakuan self-compassion therapy terhadap tingkat depresi pada subyek penelitian. Selain itu adanya penurunan tingkat depresi setelah pemberian intervensi self-compassion therapy dapat dilihat dari hasil pengukuran depresi setelah diberikan perlakuan yakni dari 17 responden, 5 orang $(29,4 \%)$ sudah dikategorikan tidak depresi, 9 orang $(52,9 \%)$ dikategorikan depresi ringan, dan 3 orang $(17,6 \%)$ dikategorikan depresi sedang. Hal tersebut 
I Gusti Ayu Harini, I Putu Yoan Sugiantara, I Wayan Candra. Desember 2021. 14 (2): 185-199

sudah mengalami penurunan skor dari sebelum pemberian intervensi atau perlakuan self-compassion therapy. Dengan demikian menunjukan bahwa selfcompassion therapy dapat memberikan pengaruh yang yakni penurunan tingkat depresi pada subyek penelitian para pasien diabetes melitus.

Peneliti sejenis yang mendukung salah satunya adalah penelitian dengan judul Peran Self-Compassion Terhadap Kecerdasan Emosi Pada Remaja Tunadaksa dengan jumlah subyek penelitian sebanyak 40 orang dengan depresi. Pada penelitian ini, responden diberikan self-compassion therapy dan mendapatkan hasil analisis Anova untuk keseluruhan model regresi menghasilkan skor $\mathrm{F}=17,722$ dan $\mathrm{p}=0,000(\mathrm{p}<0,01)$ yang artinya self-compassion memberikan sumbangan efektif paling tinggi pada kecerdasan emosi ${ }^{(16)}$.

Pada penelitian lain dengan judul Self-Compassion Intervention Untuk Menurunkan Depresi Remaja Penyintas Sex Abuse menunjukan bahwa pemberian self-compassion berpengaruh pada depresi remaja penyintas sex abuse. Secara deskriptif terlihat bahwa skor BDI-II pada responden 1 yang mulanya memiliki rata-rata 28 (kategori sedang) turun menjadi 22 (kategori sedang), sedangkan pada responden 2 mulanya memiliki rata-rata 19 (kategori ringan) turun menjadi 14 (kategori ringan) sehingga dapat disimpulkan bahwa ada pengaruh selfcompassion untuk menurunkan depresi remaja penyintas sex abuse ${ }^{(14)}$.

Penelitian lain yang berjudul Pengaruh Self-Compassion Secara Daring Terhadap Penerimaan Diri Pada Mahasiswa Dengan Fobia Spesifik Ringan dengan subyek penelitian sebanyak 26 orang yang dibagi menjadi kelompok kontrol dan kelompok eksperimen. Hasil dari uji friedman menunjukan hasil $\mathrm{p}=$ $0,018<0,05$ yang berarti self-compassion memberikan pengaruh penurnan fobia spesifik ringan pada mahasiswa tahun pertama Fakultas Psikologi Universitas Diponegoro ${ }^{(17)}$.

Menurut peneliti hasil penelitian ini memiliki pengaruh seperti yang sudah dilakukan oleh para peneliti sebelumnya, yaitu bahwa self-compassion therapy dapat berpengaruh menurunkan tingkat depresi subyek penelitian atau responden yang dalam hal ini pasien diabetes melitus dengan rata-rata tingkat depresi menjadi dalam rentang kategori depresi minimal, depresi ringan, dan depresi 
I Gusti Ayu Harini, I Putu Yoan Sugiantara, I Wayan Candra. Desember 2021. 14 (2): 185-199

sedang. Berdasarkan dari hasil penelitian dan juga teori yang sudah ada oleh beberapa ahli, maka peneliti memiliki pendapat bahwa subyek penelitian pasien diabetes melitus rentan mengalami gangguan psikologis yang tentunya memerlukan sebuah psikoterapi untuk mengatasinya sehingga dapat membantu memperbaiki manajemen perawatan diri dan juga dapat menstabilkan emosinya $^{(13)}$.

Karakteristik subyek penelitian yang telah terkait dengan tingkat depresi dianalisis menggunakan teknik analisa Chi-Square.

Tabel 7. Hasil Analisa Tingkat Depresi Berdasarkan Usia

\begin{tabular}{|c|c|c|c|c|c|c|}
\hline \multirow{3}{*}{ Usia } & \multicolumn{4}{|c|}{ Tingkat Depresi } & \multirow{3}{*}{ Jumlah } & \multirow{3}{*}{$p$-value } \\
\hline & \multicolumn{2}{|c|}{ Ringan } & \multicolumn{2}{|c|}{ Sedang } & & \\
\hline & $\mathbf{n}$ & $\%$ & $\mathbf{n}$ & $\%$ & & \\
\hline $31-59$ & 8 & 47,1 & 6 & 35,3 & 82,4 & \\
\hline$\geq 60$ & 2 & 11,8 & 1 & 5,9 & 17,6 & 0,761 \\
\hline Jumlah & 10 & 58,8 & 7 & 41,2 & 100 & \\
\hline
\end{tabular}

Tabel 7 menunjukan tingkat depresi berdasarkan usia dengan $p$-value 0,761 artinya tidak terdapat hubungan usia dengan depresi.

Tabel 8. Hasil Analisa Tingkat Depresi Berdasarkan Jenis Kelamin

\begin{tabular}{|c|c|c|c|c|c|c|}
\hline \multirow{3}{*}{ Jenis Kelamin } & \multicolumn{4}{|c|}{ Tingkat Depresi } & \multirow{3}{*}{ Jumlah } & \multirow{3}{*}{$p$-value } \\
\hline & \multicolumn{2}{|c|}{ Ringan } & \multicolumn{2}{|c|}{ Sedang } & & \\
\hline & n & $\%$ & $\mathbf{n}$ & $\%$ & & \\
\hline Laki-Laki & 7 & 41,2 & 0 & 0 & 41,2 & \\
\hline Perempuan & 3 & 17,6 & 7 & 41,2 & 58,8 & 0,004 \\
\hline Jumlah & 10 & 58,8 & 7 & 41,2 & 100 & \\
\hline
\end{tabular}

Tabel 8 menunjukan bahwa tingkat depresi berdasarkan pada jenis kelamin dengan $p$-value 0,004 yang artinya ada hubungan antara jenis kelamin dengan depresi.

\section{Hubungan Tingkat Depresi Berdasarkan Usia}

Hasil penelitian menunjukan nilai $p$-value 0,761 yang artinya bahwa tingkat depresi berdasarkan usia tidak terdapat hubungan atau dengan kata lain tidak ada hubungan antara tingkat depresi terhadap usia. Penelitian dengan judul Hubungan 
I Gusti Ayu Harini, I Putu Yoan Sugiantara, I Wayan Candra. Desember 2021.

14 (2): 185-199

Antara Usia dan Jenis Kelamin dengan Tingkat Depresi pada Lansia di Panti Jompo Kabupaten Karawang Jawa Barat dengan jumlah responden sebanyak 76 orang juga menunjukan hal serupa karena berdasarkan hasil analisis statistik pada penelitian tersebut dengan uji Fisher's-Exact pada CI $95 \%$ dengan $\alpha=0,05$ diperoleh nilai $\mathrm{p}=0,691(\mathrm{p}>\alpha)$ menunjukkan tidak ada perbedaan proporsi yang signifikan antara mereka yang kelompok usia lansia elderly (60-74 tahun) dengan kelompok usia lansia old (75-90 tahun) terhadap tingkat depresi ${ }^{(18)}$.

Penelitian lain dilakukan oleh Herawati dan Deharnita $(2019)^{(19)}$ berjudul Relationship Characteristics With Incidence Of Depression In The Elderly dengan jumlah responden yang mengalami depresi sebanyak 72 orang, setelah dilakukan uji Chi-Square didapatkan nilai $p$-value $=0.516>0,05$. Sehingga disimpulkan pada kedua penelitian tersebut juga tidak terdapat hubungan tingkat depresi berdasarkan usia pada masing-masing subyek penelitiannya.

\section{Hubungan Tingkat Depresi Berdasarkan Jenis Kelamin}

Hasil penelitian menunjukan nilai $p$-value 0,004 yang artinya bahwa tingkat depresi berdasarkan jenis kelamin terdapat hubungan atau dengan kata lain ada hubungan antara tingkat depresi terhadap jenis kelamin. Menurut hasil penelitian dengan judul Hubungan Pendidikan, Jenis Kelamin Dan Status Perkawinan Dengan Depresi Pada Lansia dengan jumlah responden yang mengalami depresi sebanyak 22 orang menunjukan hasil bahwa sebagian besar lansia berjenis kelamin perempuan $(67,9 \%)$ mengalami depresi dibandingkan laki-laki, hal ini dibuktikan dengan uji statistik menunjukan p-value $0,012<0,05^{(20)}$. Penelitian yang mendukung lainnya yang berjudul Proporsi Depresi pada Penderita Diabetes Melitus Tipe 2 di RSUP Sanglah Denpasar dengan jumlah responden sebanyak 40 orang yang menderita depresi, menunjukan bahwa sebagian besar kejadian depresi lebih tinggi ditemukan pada perempuan $(80,0 \%)$. Jadi pada penelitian ini dapat disimpulkan bahwa terdapat atau ada hubungan tingkat depresi terhadap jenis $\operatorname{kelamin}^{(21)}$.

Menurut pendapat peneliti perbedaan jenis kelamin yang dimiliki oleh para subyek penelitian dalam perkembangan masalah-masalah emosional yang ada 
I Gusti Ayu Harini, I Putu Yoan Sugiantara, I Wayan Candra. Desember 2021.

14 (2): 185-199

sangat mempengaruhi persepsi dan juga pengontrolan diri masing masing mereka. Dalam penelitian ini, responden perempuan lebih mudah mengalami rangsangan stresor dari pada laki-laki. Pada tahap pengukuran tingkat depresi, responden perempuan cenderung lebih banyak berbicara ketika mencurahkan masalah yang dialami serta dirasakan.

\section{SIMPULAN}

Berdasarkan hasil penelitian yang telah dilakukan dapat disimpulkan bahwa tingkat depresi pada subyek penelitian di Wilayah Kerja Puskesmas I Denpasar Barat tahun 2021 sebelum diberikan self-compassion therapy sebagian besar dalam kategori depresi ringan sebanyak 10 orang $(58,8 \%)$, dan kategori depresi sedang 7 orang responden $(41,2 \%)$. Tingkat depresi subyek penelitian di Wilayah Kerja Puskesmas I Denpasar Barat tahun 2021 sesudah diberikan tindakan selfcompassion therapy mengalami penurunan menjadi kategori depresi sedang sebanyak 3 orang responden (17,6\%), kategori depresi ringan sebanyak 9 orang responden $(52,9 \%)$, dan tidak depresi sebanyak 5 orang $(29,4 \%)$. Ada pengaruh pemberian self-compassion therapy terhadap tingkat depresi pada subyek penelitian di Wilayah Kerja Puskesmas I Denpasar Barat tahun 2021, ditunjukan dengan hasil $\mathrm{p}$-value yang terdapat $=0,000$.

\section{UCAPAN TERIMA KASIH}

Peneliti mengucapkan terimakasih kepada Kepala Puskesmas I Denpasar Barat dan staff yang telah memberikan izin dan membantu dalam melakukan penelitian di wilayah kerja Puskesmas I Denpasar Barat serta kepada semua pihak yang terlibat dan membantu dalam penelitian ini.

\section{ETHICAL CLEARENCE}

Persetujuan etika peneltian ini diperoleh dari komisi etik penelitian Politeknik Kesehatan Kemenkes Denpasar dengan nomor surat LB.02.03/EA/KEPK/0308/ 2021. 
I Gusti Ayu Harini, I Putu Yoan Sugiantara, I Wayan Candra. Desember 2021.

14 (2): 185-199

\section{DAFTAR RUJUKAN}

1. Kemenkes RI (2019) 'Hari Diabetes Sedunia Tahun 2018', Pusat Data dan Informasi Kementrian Kesehatan RI.

2. Hestiana, D. W. (2017) 'Faktor-Faktor Yang Berhubungan Dengan Kepatuhan Dalam Pengelolaan Diet Pada Pasien Rawat Jalan Diabetes Mellitus Tipe 2 Di Kota Semarang', Jurnal of Health Education, 2 (1).

3. Paramita, P. D. G., Candra, I. W. dan Harini, I. G. A. (2019) 'Terapi Eye Movement Desensitization And Reprocessing Terhadap Tingkat Stres Pasien Diabetes Melitus', Jurnal Gema Keperawatan, (1).

4. Wahyuni, K. D. dan Candra, I. W. (2019) 'Pengaruh Pelatihan Panca Cara Temuan Makna Terhadap Penurunan Tingkat Depresi Pada Pasien Diabetes Melitus', Jurusan Keperawatan Politeknik Kesehatan Denpasar.

5. Candra, I. W. dan Epriliani, P. (2019) 'Mindfullness-Based Cognitive Therapy (MBCT) Menurunkan Tingkat Depresi’, Jurnal Gema Keperawatan, $12(2)$.

6. Sorayah (2014) 'Uji Validitas Konstruk Beck Depression Inventory-II ( BDIII )', UIN Syarif Hidayatullah Jakarta, 1.

7. Chairunnisa, A. dan Fourianalistyawati, E. (2019) 'Peran Self-Compassion Dan Spiritualitas Terhadap Depresi Pada Ibu Hamil', Jurnal Psikologi Ulayat, 6.

8. Kawitri, A. Z., Rahmawati, B. D., Arruum, R. dan Rahmatika, R. (2019) 'Self-Compassion and Resilience among Adolescents Living at Social Shelters', Jurnal psikogenesis, 7 (1).

9. Ramadhani, F. dan Nurdibyanandaru, D. (2014) 'Pengaruh Self-Compassion terhadap Kompetensi Emosi Remaja Akhir', CIRED - Open Access Proceedings Journal, 3 (03).

10. Supriati, L., Handayani, T., dan Ilmansyah, F. A. (2016) 'Hubungan Dukungan Keluarga dengan Kejadian Depresi pada Pasien Diabetes Mellitus di Rumah Sakit Muhammadiyah Gresik', Majalah Kesehatan Prodi Ilmu Keperawatan FKUB, 3 (4).

11. Umamah, F. dan Hidayah, L. (2017) 'The Laughter Therapy on the Depression Level Experienced by the Elderly in UPTD Panti Griya Wreda Surabaya', Jurnal Ilmiah Kesehatan, 10 (1).

12. Lubis, N. L. (2016) Depresi Tinjauan Psikologis. 2nd edn, Kencana. 2nd edn. Edited by Jeffry dan C. Design. Jakarta: PT. Fajar Interpratama Mandiri.

13. Hartanti., Pudjibudojo, J. K., Aditama, L., Rahayu, R. P. (2013) Pencegahan dan Penanganan Diabetes Mellitus, Pendekatan Medis, Farmakologis, dan Psikologis. 1st edn. Edited by W. Chintya and M. Aditya. Surabaya: Fakultas Psikologi Universitas Surabaya.

14. Tsani, D. R. K., Hartanti dan Elishabeth, M. P. (2020) 'Self-Compassion Intervention Untuk Menurunkan Depresi Remaja Penyintas Sex Abuse', Ristekdik (Jurnal Bimbingan dan Konseling), 5 (2).

15. American Diabetes Association (2017) 'Standards of Medical Care in Diabetes - 2017', The Journal Of Clinical And Applied Research And Education, Volume 40 (Suppement 1). 
I Gusti Ayu Harini, I Putu Yoan Sugiantara, I Wayan Candra. Desember 2021. 14 (2): 185-199

16. Septiyani, D. A. dan Novitasari, R. (2017) 'Peran Self-Compassion Terhadap Kecerdasan Emosi Pada Remaja Tunadaksa', Jurnal Indigenous Prodi Psikologi Fakultas Psikologi dan Ilmu Sosual Budaya Universitas Islam Indonesia, 2 (1).

17. Indrawati, N. D. (2020) 'Pengaruh Self-Compassion Secara Daring Terhadap Penerimaan Diri Pada Mahasiswa Dengan Fobia Spesifik Ringan', Fakultas Psikologi Universitas Diponegoro, 1.

18. Shafa, G. N., Nurhayati, E. dan Indriyanti, R. A. (2016) 'Hubungan Antara Usia dan Jenis Kelamin dengan Tingkat Depresi pada Lansia di Panti Jompo Kabupaten Karawang Jawa Barat', Prodi Pendidikan Kedokteran Fakultas Kedokteran Universitas Islam Bandung, 2 (2).

19. Herawati, N. dan Deharnita, D. (2019) 'Relationship Characteristics With Incidence Of Depression In The Elderly', Jurnal Keperawatan Jiwa, 7 (2).

20. Sutinah dan Maulani (2017) 'Hubungan Pendidikan, Jenis Kelamin Dan Status Perkawinan Dengan Depresi Pada Lansia', Jurnal Endurance Prodi NERS STIKES Harapan Ibu Jambi, 2(2).

21. Krisnawan, G. A. E., Aryani, P. dan Sari, K. A. K. (2019) 'Proporsi Depresi pada Penderita Diabetes Melitus Tipe 2 di RSUP Sanglah Denpasar', Intisari Sains Medis, 10 (2). 